\title{
26. REGIONAL ASPECTS OF DEEP-WATER DRILLING IN THE GULF OF MEXICO, EAST OF THE BAHAMA PLATFORM AND ON THE BERMUDA RISE ${ }^{1}$
}

\author{
Maurice Ewing \& J. Lamar Worzel, Lamont-Doherty Geological Observatory, Palisades, New York \\ and \\ Creighton A. Burk, Mobil Oil Corporation, Princeton, New Jersey
}

Holes were drilled and cored at seven different sites during the pioneering cruise of the Glomar Challenger in the late summer of 1968. In addition to the large amount of important geological information that was obtained, many of these holes set ņew records for depth of water, penetration below the sea floor, length of drill pipe used in the deep ocean, distance from shore, and others. These seven sites fall naturally into three groups of closely related objectives and areas;

${ }^{1}$ Lamont-Doherty Geological Observatory of Columbia University contribution Number 1370 . this summary will discuss the regional results according to these three broader areas.

\section{GULF OF MEXICO}

The deepest part of the Gulf of Mexico is occupied by the extremely flat and level floor of the Sigsbee abyssal plain, which is broken only by a number of small hills, or knolls, which rise a few hundred meters above the floor of this plain in its southwestern part as indicated in Figure 1. This abyssal plain is bordered on its southern and eastern side by scarps which lead steeply upward to the carbonate platforms of the

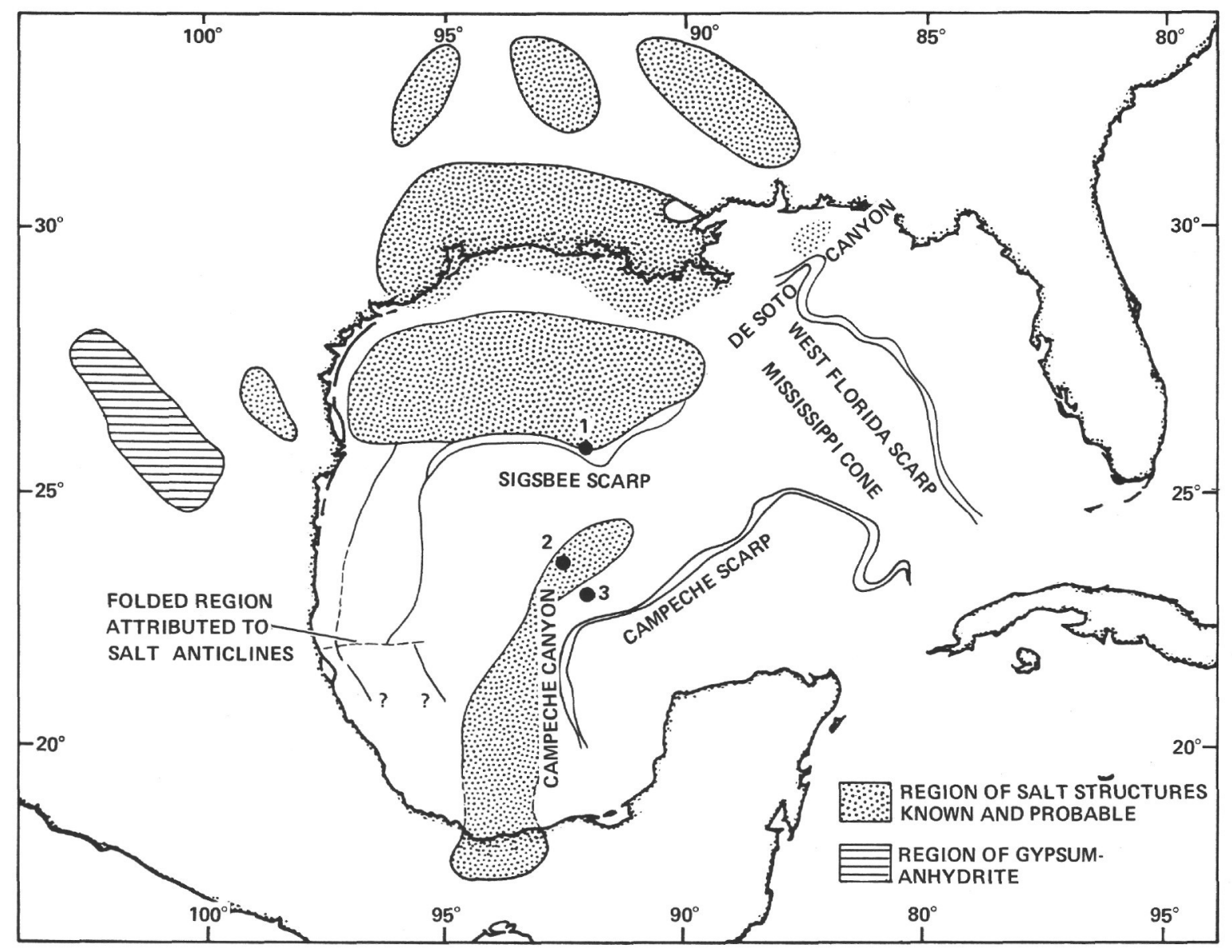

Figure 1. Sketch of the Gulf of Mexico area, showing location of the Mississippi Cone and the scarps which bound the central plain. Areas of known or suspected salt and gypsum-anhydrite deposits are indicated by stippling. 
Campeche and West Florida shelves. The western margin of the plain leads up the irregular surface of the Eastern Mexico continental slope, recently found to be underlain by long anticlinal ridges parallel to the shelf edge, which may represent the early stages of salt flowage.

The northern edge of the plain is bounded by the low, but steep, Sigsbee Scarp, which also borders the broad, irregular surface of the Texas continental slope (much of the irregularity of which appears to be the result of salt diapirism). At the eastern edge of this irregular slope is the hummocky accumulation of sediments forming the Mississippi Cone, which leads gradually into the Sigsbee Abyssal Plain. It is now known that at least 10 kilometers of sediment underlie the upper part of this slope and fan, and at least half this much underlies the northern edge of the abyssal plain, gradually thinning southward toward the Campeche Scarp.

Site 1 was located at the base of the Sigsbee Scarp. Site 2 was drilled into the top of one of the Sigsbee Knolls, and Site 3 was located in the southern part of the abyssal plain away from disturbance by the knolls (Figure 1).

The regional importance of the three sites selected in the Gulf of Mexico is perhaps best indicated by some of the investigations which eventually lead to their selection. As early as 1953 studies of 33 piston cores obtained in the Gulf of Mexico by Lamont-Doherty Geological Observatory indicated that turbidites derived largely from Pleistocene debris provided by the Mississippi River were responsible for the flat floor of the Sigsbee Abyssal Plain. Refraction seismic data suggested further that the underlying crust was thin and of oceanic character (Ewing et al., 1955).

In 1954, Lamont-Doherty took 124 additional piston cores and discovered the Sigsbee Knolls. In contrast to the surrounding plain, cores from the three newlydiscovered knolls contained only pelagic deposits dating well back into the Pleistocene (Ewing et al., 1958). At this time, these knolls were interpreted to be the expression of diapirs, probably salt. The continuous seismic profiler was used in the Gulf of Mexico for the first time in 1961 by Lamont-Doherty, and numerous similar diapirs were found nearby, completely buried by the enclosing sediments (Ewing, Worzel, and Ewing, 1962). It was suggested in that report that the knolls and submerged domes were derived from the midMesozoic Louann salt or its correlatives. Subsequent surveys have shown that this field of diapirs extends southwest in a continuous belt toward the VeracruzTabasco salt diapirs of the Isthmus of Tehuantepec (Worzel et al., 1968), as shown in Figure 1.

\section{Site 1}

Site 1 was selected and drilled largely as an engineering test of the drilling equipment and procedures. It appears that it was situated in a slight embayment into the Sigsbee Scarp. The cores consist of brown to tan unconsolidated silts and clays, all poor in fossils. The sparse fossils consist of a mixture of Pleistocene and reworked Upper Cretaceous nannoplankton, and all of the section is interpreted to be of Recent to Pleistocene age. Well logs suggest the possible presence of lithologies different from those of the cored intervals, and it may be that they represent Pleistocene interglacial stages. The clays appear to be fairly homogeneous throughout the cores, indicating that all were probably derived from a single source. The bathymetric configuration of the Gulf of Mexico suggests that this source is probably the Mississippi Cone and initially the Mississippi River. Assuming that the entire two million years since the start of the Pleistocene is represented by the total depth of the hole, the minimum rate of accumulation is very high, approximately $38 \mathrm{~cm} / 10^{3}$ years (for these purposes it seemed unnecessary to make allowances for the repetition of beds in chevron foldings). The sediment is fairly rich in detrital carbonate of unknown origin, and the sequence is partly laminated by silt in thin, graded beds.

A feature in the cores at Site 1 of considerable regional interest is the prominent deformation which they display, especially in the lower part. Small, sharp, chevron folds are abundant, with a wave length commonly of the order of a decimeter, and with essentially horizontal axial planes. Seismic reflection data in the vicinity of Site 1 shows an interval of strongly diffracted arrivals overlying a sequence of evenly layered reflectors. This interval of diffractions extends for a considerable distance south of the scarp and may correspond in part to the highly deformed beds noted in the cores (Figure 2).

These small folds may owe their origin to lateral stresses generated in the continental slope north of the adjacent scarp (as by lateral movement of salt diapirs or sills). It does not seem reasonable to expect, however, that these unconsolidated and uncemented sediments would be able to transmit such stresses for any significant distance away from the scarp as is suggested by the seismic reflection data. It also appears unlikely that these sediments could remain intact over long distances, as would be necessary if they represented mass movement of material accumulated initially on the adjacent continental slope. It seems more probable that these water-saturated sediments may have moved laterally for only short distances but repeatedly, under the force of gravity, due perhaps to a slight steepening of the depositional surface; or alternatively, they could have been emplaced by mass movement down the slope 


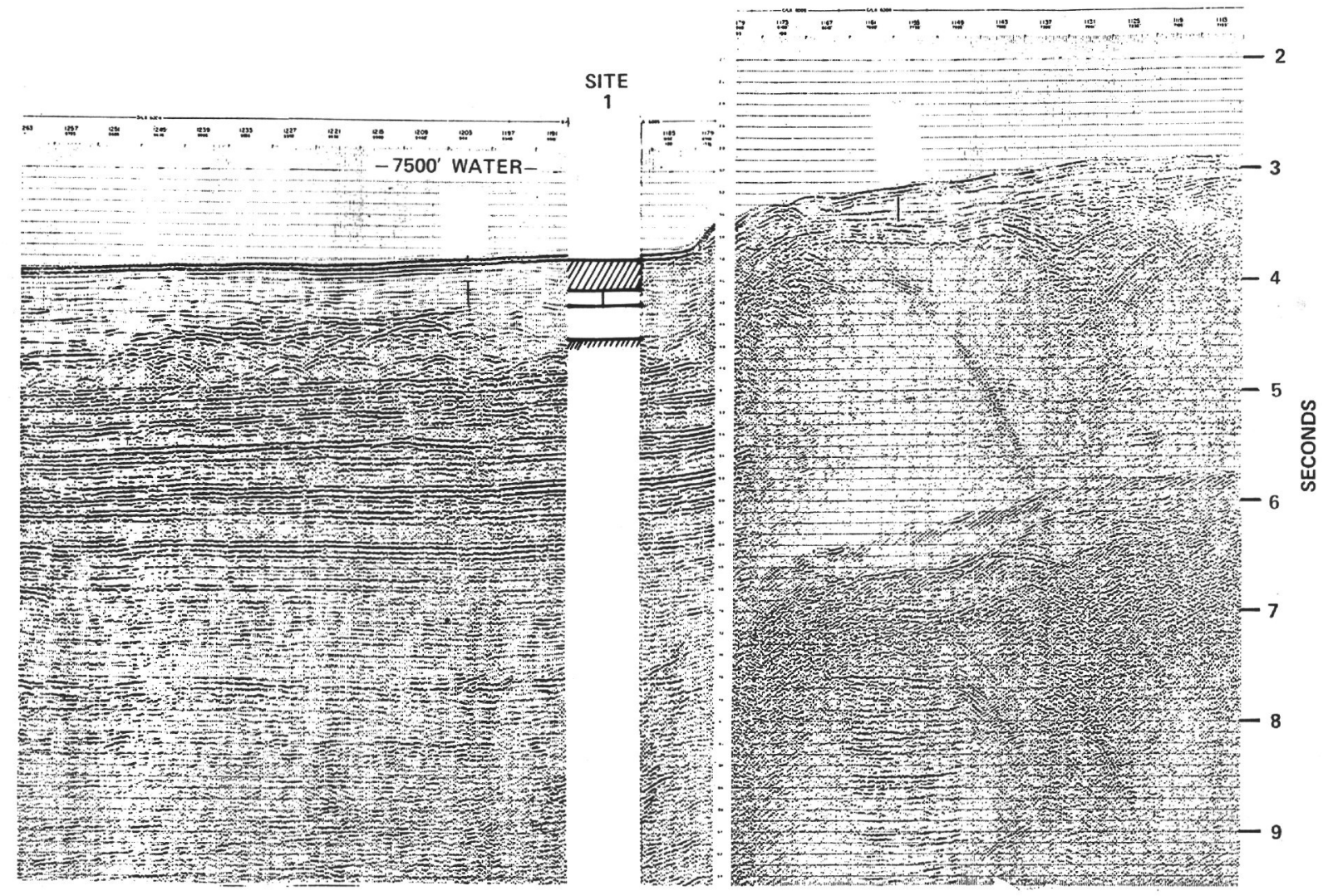

Figure 2. Seismic reflection profile near Site 1.

before the formation of the Sigsbee Scarp-unless it can be shown that the scarp is older than these sediments.

\section{Site 2}

The particular abyssal prominence selected for Site 2 was named Challenger Knoll by the shipboard scientists. The profiler traverse on which the site was selected is shown in Figure 3. Note the layer, 100-200 meters thick, of homogeneous, unstratified section which caps the domes and separates the diapir from the stratified turbidites. The precision depth recorder traverse (Figure 4) of Challenger Knoll represents a topographic pattern which probably has prevailed since late Miocene, since all of the unconsolidated sediments cored here were pelagic. The upper Pleistocene consists largely of calcareous ooze and clay minerals. The lower Pleistocene and Pliocene are purely calcareous oozes, and a single chip of late Miocene is also a calcareous ooze with a prominent admixture of volcanogenic clays. This general sequence within the Challenger Knoll pelagic deposits is closely reflected in the turbidites of the surrounding abyssal plain, as will be noted later in connection with Site 3.
An interpretation of the results at Site 2 is shown in Figure 5 (by Burk). Cap rock was encountered at a depth near 136 meters ( 447 feet), still nearly 45 meters (150 feet) above the adjacent abyssal plain. The cap rock is typical of that formed over salt diapirs throughout the northern margin of the Gulf of Mexico and elsewhere in the world, consisting largely of calcite and gypsum. Cap rock is considered to form from the relatively insoluble residues in the salt which collect at the top of a diapir as the salt is dissolved by circulating waters. Normally this residue is anhydrite, which subsequently may alter to calcite and sulphur; the sulphur content reaches nearly 20 per cent in parts of the core. The generation of sulphur requires the presence of organic matter, which in this case is petroleum. The carbon in the calcite was also originally in the petroleum.

Studies of this cap rock, coordinated by the American Petroleum Institute, confirm these interpretations in regard to the origin of the Challenger Knoll cap rock, and further suggest that the petroleum itself is very young. Carbon isotope data and molecular size 


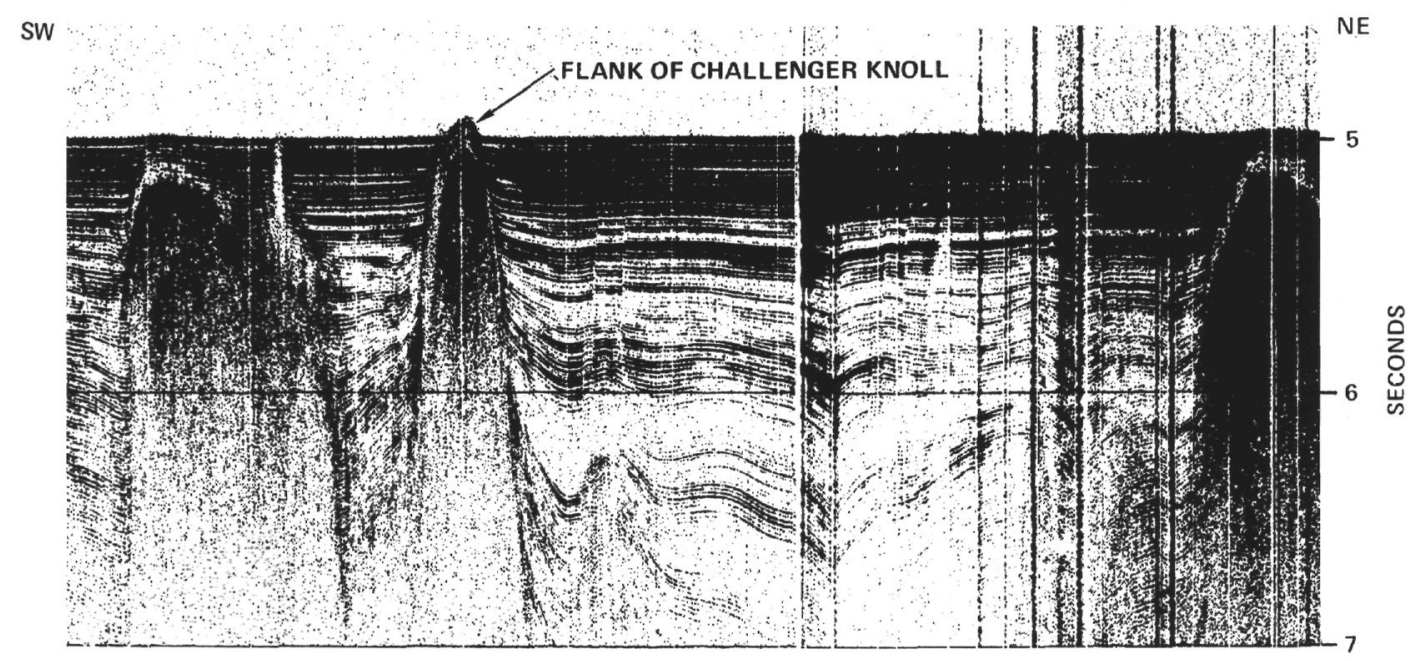

Figure 3. A portion of the Vema-24 profiler traverse on which the selection of Site 2 was based.

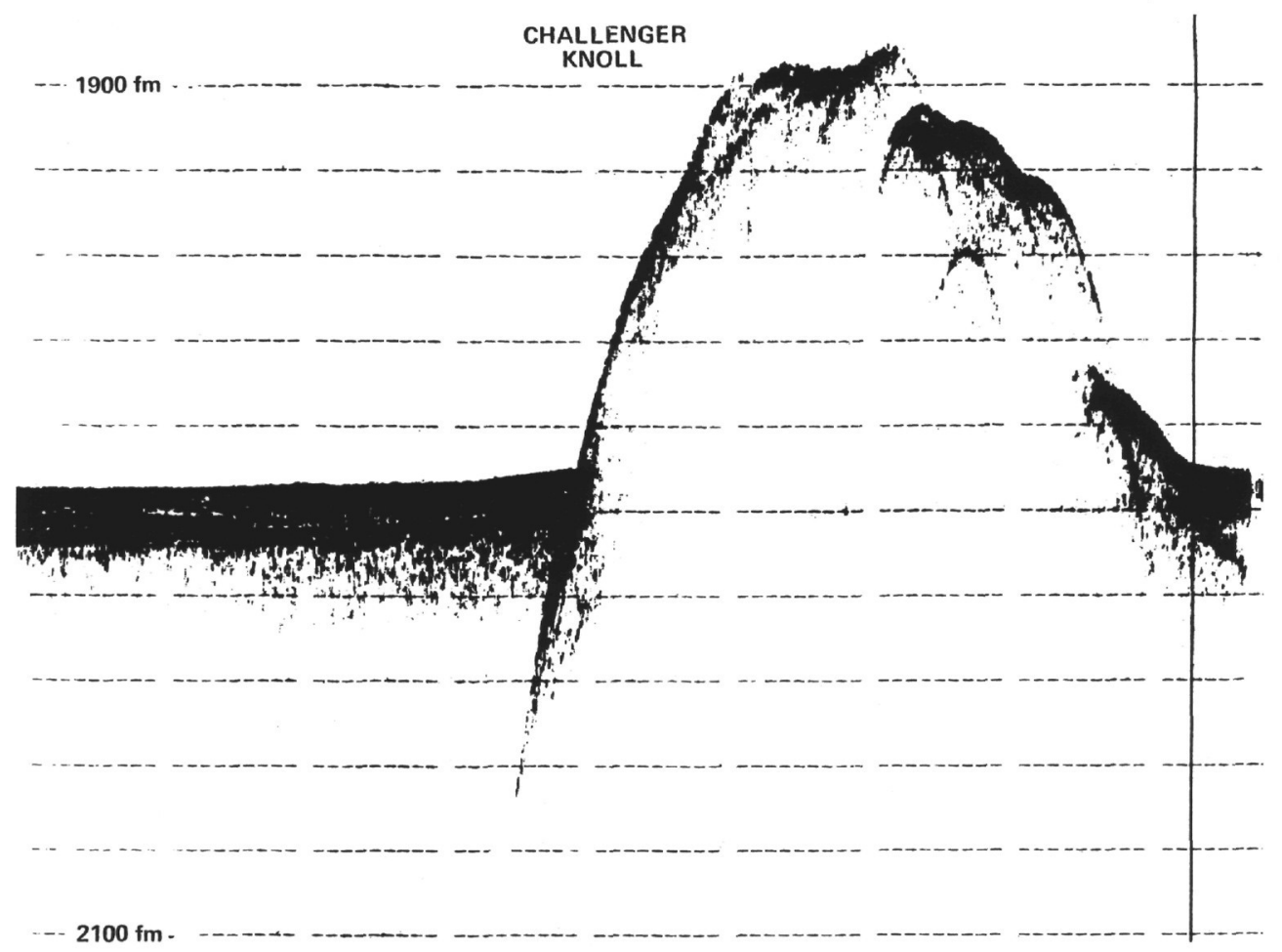

Figure 4. Precision Depth Recorder traverse of Challenger Knoll, near Site 2.

distributions of the porphyrins are consistent with the concept of the origin of the petroleum from marine organic material, and other geochemical data also suggest a young, immature crude. The oil is of low gravity and high sulphur content.

Abundant pollen grains and spores, similarly concentrated as insoluble residues in the cap rock, were identified as probably Middle to Upper Jurassic to possibly Lower Cretaceous.
The pelagic character of the sediments overlying the Challenger diapir suggests that it has been a topographic knoll at least since the late Miocene, and the thinning of the flanking sediments in seismic reflection profiles suggests that it is still growing. It also seems apparent that cap rock can form beneath deep ocean sediments, and that petroleum and sulphur can be generated in a deep ocean environment. (Gassy, expanding cores were also noted at Site 1, and the lowest core at Site 6 also had a very strong hydrocarbon odor.) 


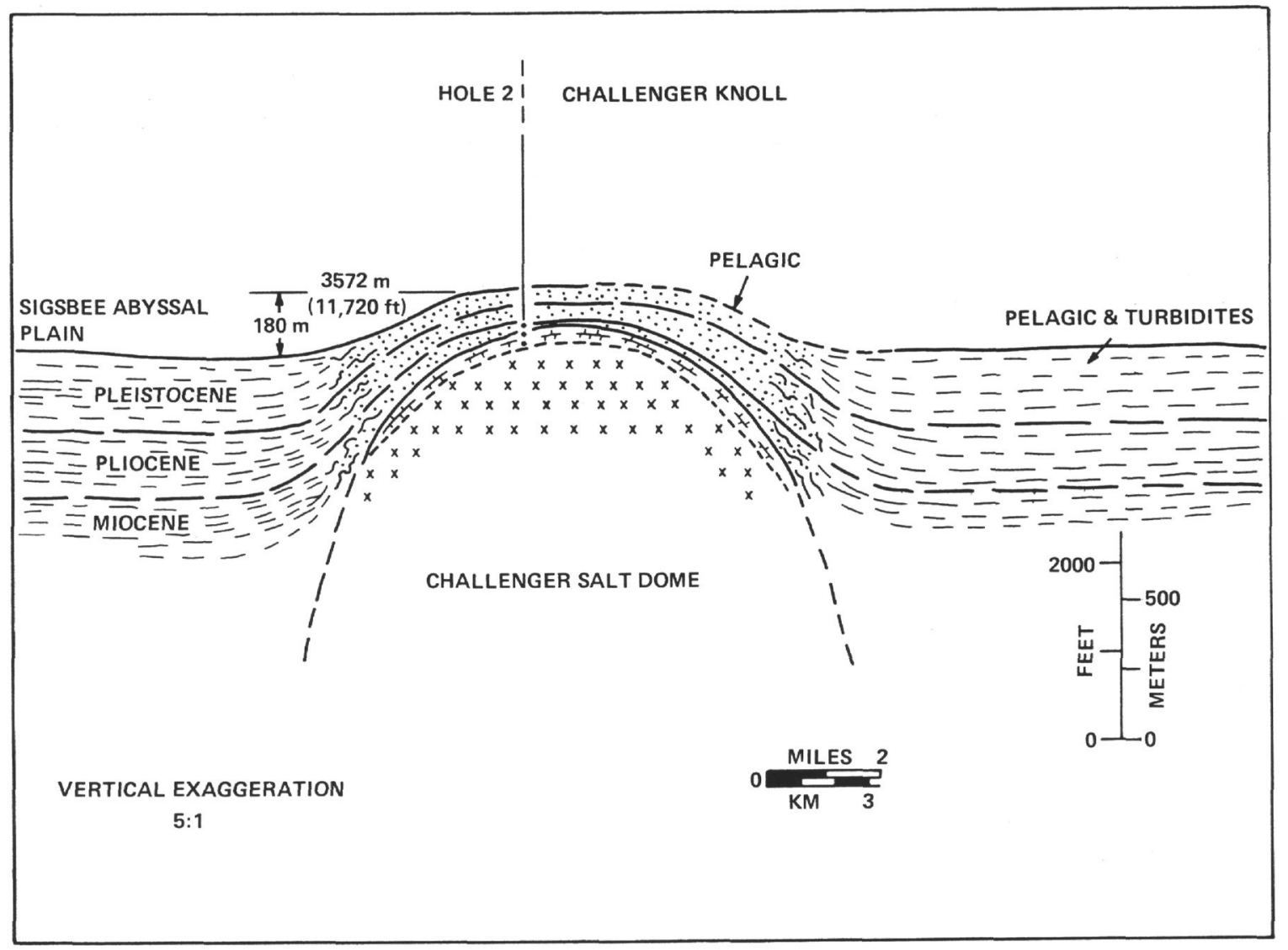

Figure 5. Structural section through Challenger Knoll, based on reflection profiler traverses and cores obtained at Sites 2 and 3 (by Burk).

It is reasonable that all of the adjacent knolls and domes are similar to the Challenger Knoll in that they are salt diapirs which owe their origin to a parent salt which is of mid-Mesozoic age throughout the Gulf of Mexico area. The regional problem which probably will be most earnestly debated in the future is whether this salt was deposited in its present deep water environment, or on a crust which was once much shallower.

\section{Site 3}

Site 3 was located in the undisturbed abyssal plain southeast of the Challenger Knoll, in order to examine an older section of turbidites and to compare them with the pelagic deposits of the Challenger Knoll. The seismic traverse on which the choice was based, reproduced in Figure 6, shows level-bedded turbidites onlapping stratified beds which dip uniformly to the northeast, presumably also turbidites. Many other seismic reflection profiles in the Gulf of Mexico have shown an overlapping of sedimentary sequences below the abyssal plain, suggesting that older turbidites may have been derived from a variety of sources other than the Mississippi River (Worzel et al., 1968).
The upper Pleistocene turbidites consist of gray, terrigenous silts and clays, not unlike those at Site 1, suggesting a source from the Mississippi Cone and River. The lower Pleistocene and Pliocene consist of bluish green coccolith oozes with thin calcareous turbidites of shallow-water biogenic debris, which become thicker and more abundant in the Lower Miocene, presumably from sources in the Campeche and West Florida shelves. The Upper Miocene contains green montmorillonitic (volcanic) clays with turbidites of volcanic rock debris, carbonaceous plant debris, quartz, some feldspar, and heavy minerals, presumably derived from the Mexican mainland.

The turbidites of the Sigsbee Abyssal Plain appear to have had different provenances at different geological times which may also reflect major geological events within the surrounding land areas. It is significant that these broad changes in the turbidites of the abyssal plain are exactly reflected in the pelagic deposits from the Challenger Knoll.

If any general pattern of abyssal plain sedimentation can be deduced from this single hole, it is that surges of 


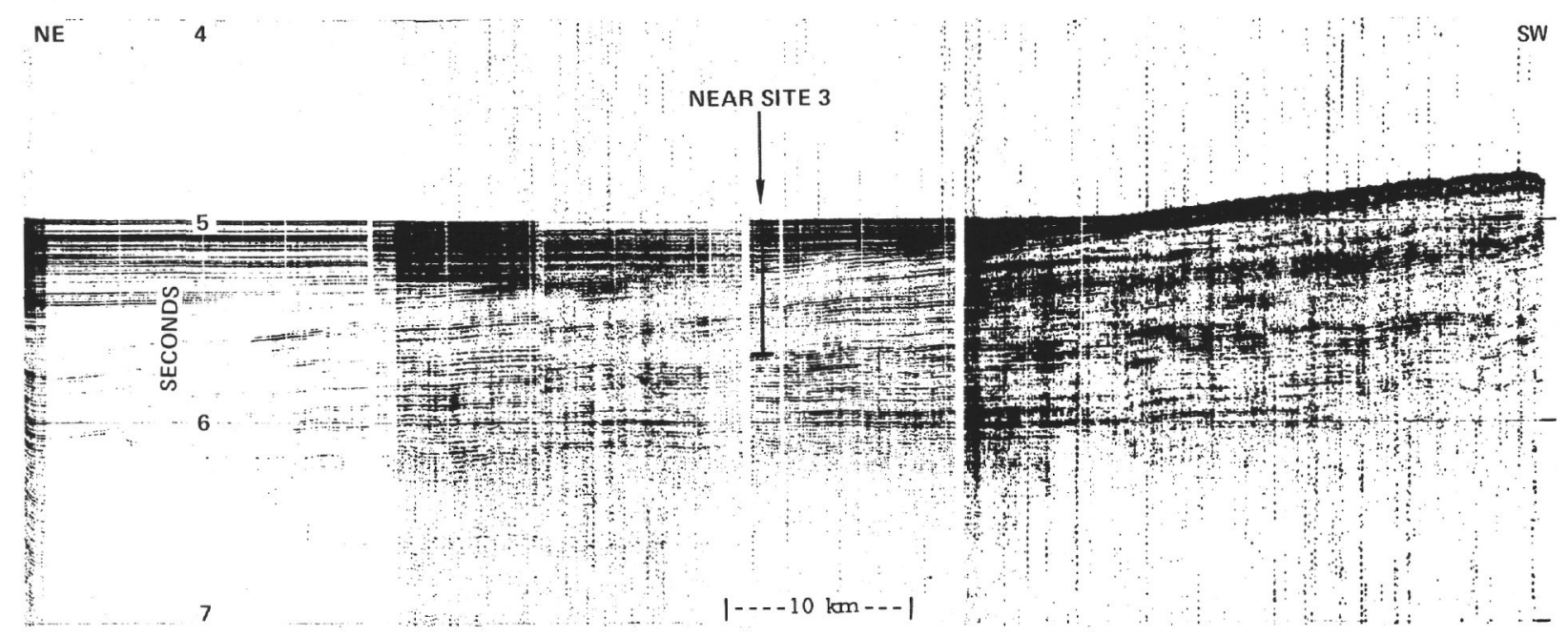

Figure 6. A portion of the Vema-24 profiler traverse on which the selection of Site 3 was based. 6 February, 1967, 0330-0930.

turbidite deposition gradually diminish through time in both thickness and frequency, giving way to largely pelagic deposits. Several subsequent surges of turbidites followed the same pattern. In the sediments cored in subsequent holes a similar pattern was generally observed.

Turbidites appear to make up about three-fourths of the total upper Pleistocene and Recent sediments of the area of Site 3, and somewhat more than half the Pliocene and lower Pleistocene sediments. The Upper Miocene turbidite component appears to exceed even that of the upper Pleistocene and Recent. This is also clear in the computed rates of sedimentation, as shown in Figure 7. At Site 3 the upper Pleistocene and Recent rates range to $46 \mathrm{~cm} / 10^{3} \mathrm{y}$ (vs. $3 \mathrm{~cm} / 10^{3} \mathrm{y}$ at Site 2) and the Pliocene averaged $3.5 \mathrm{~cm} / 10^{3} \mathrm{y}$ (vs. 1.5 $\mathrm{cm} / 10^{3} \mathrm{y}$ at Site 2). For comparison, it may be recalled that the upper Pleistocene and Recent at Site 1 accumulated at an average rate of at least $38 \mathrm{~cm} / 10^{3} \mathrm{y}$. The importance of the turbidity contribution to sediments of the plain is illustrated in Figure 8.

The data from all three sites in the Gulf of Mexico, when compared to the seismic reflection records, show that it is not unreasonable to correlate and extrapolate lithologic units of known geologic ages in great detail within the Sigsbee and other abyssal plains by utilizing a few carefully selected coring sites and high quality seismic reflection data.

\section{"HORIZON A" OUTCROP AREA}

Continuous seismic reflection profiles begun in 1961 by Lamont-Doherty Geological Observatory had revealed

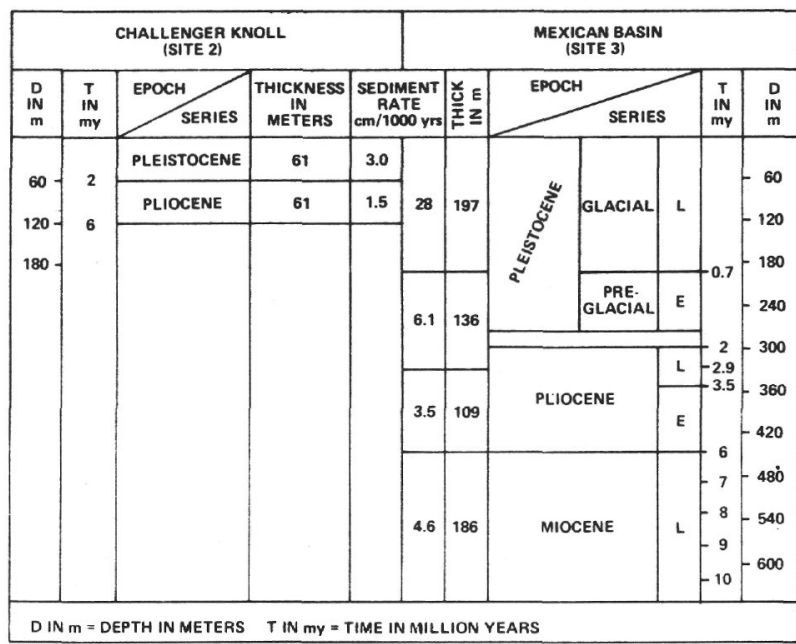

Figure 7. Late Cenozoic sediment thicknesses and rates for the Mexican Basin Plain and for Challenger Knoll.

a very extensive acoustic reflector beneath much of the Atlantic Ocean (Ewing and Ewing, 1962), which was referred to as "Horizon A". This was considered to be the result of a widespread flood of turbidites, probably late Cretaceous in age (Ewing, 1963). Surveys during 1961, combined with several other traverses in later years, indicated that a small area east of the Bahama Islands contained outcrops of beds older than Horizon A, because of a zone of deeper reflectors-referred to as "Horizon B" (Ewing et al., 


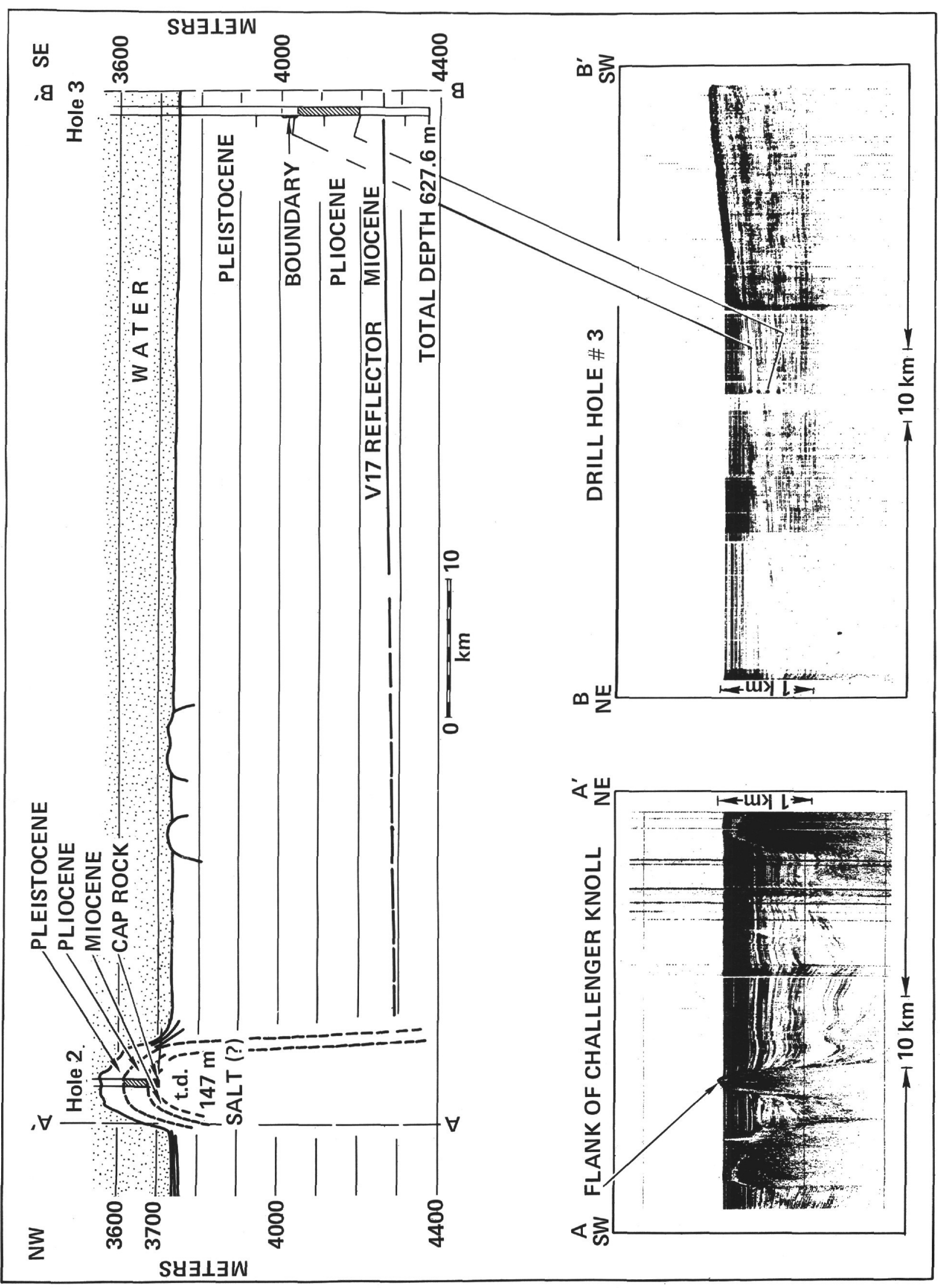

Figure 8. Structure section from Site 2 to Site 3. 
1966)-which appeared to crop out in this area, as shown in Figure 9.

Several attempts were made to sample these old sediments, under the guidance of the profiler surveys, but since a veneer of young sediment that is too thin to measure with the profiler may be too thick to penetrate by piston coring, not all of them were successful. As is shown in Figure 10, piston coring in the area northeast of the Bahaman island of San Salvador (Windisch et al., 1968) recovered Aptian-Albian and Cenomanian sediments in the northwest part of the area, Maestrichtian rocks to the east (near Horizon A), and Neocomian sediments (Hauterivian-Barremian) near the center of the area, below the top of Horizon $\beta$. Examples of the seismic traverses on which Sites 4 and
5 were selected are shown in Figure 11, with the ages inferred from piston coring. Two small hills near Site 5 might possibly represent outcrops of the acoustic basement, perhaps older than Horizon $\beta$. (The larger of these two hills was referred to as Mt. Reproach by the shipboard scientists).

Sites 4 and 5 were located in the area of these exposures between the Hatteras Abyssal Plain and the Bahama Platform. On the assumption that these sediments would not present serious drilling problems, the hope was to reach definitive geophysical markers after sampling a maximum of sedimentary section.

Site 4 , in an area free from structural complications (Figure 12), revealed chert layers and very hard drilling.

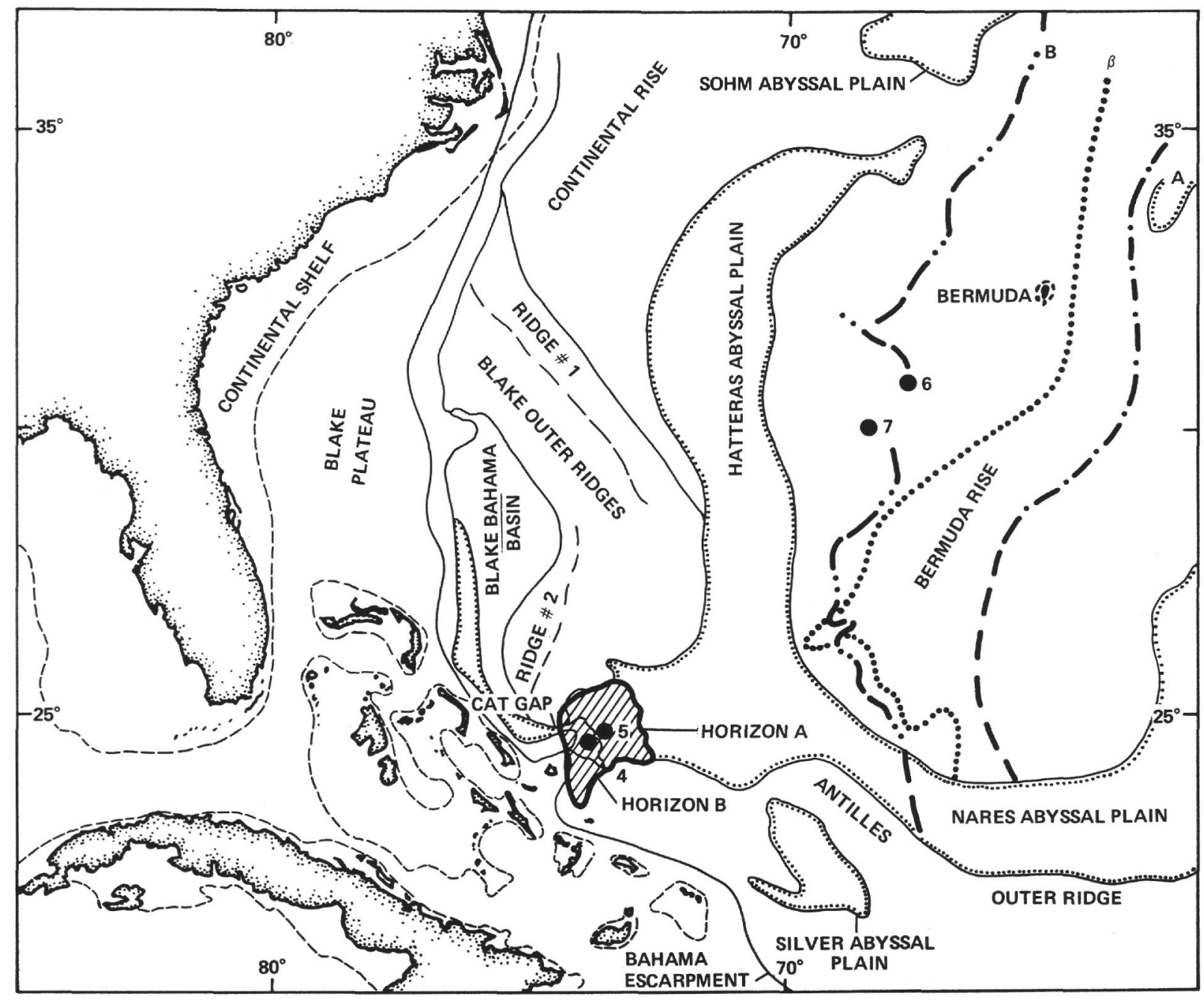

Figure 9. Location map for Sites 4, 5, 6, and 7, showing physiographic provinces, and eastward limit of seismic Horizons $A, \beta$, and $B$. 


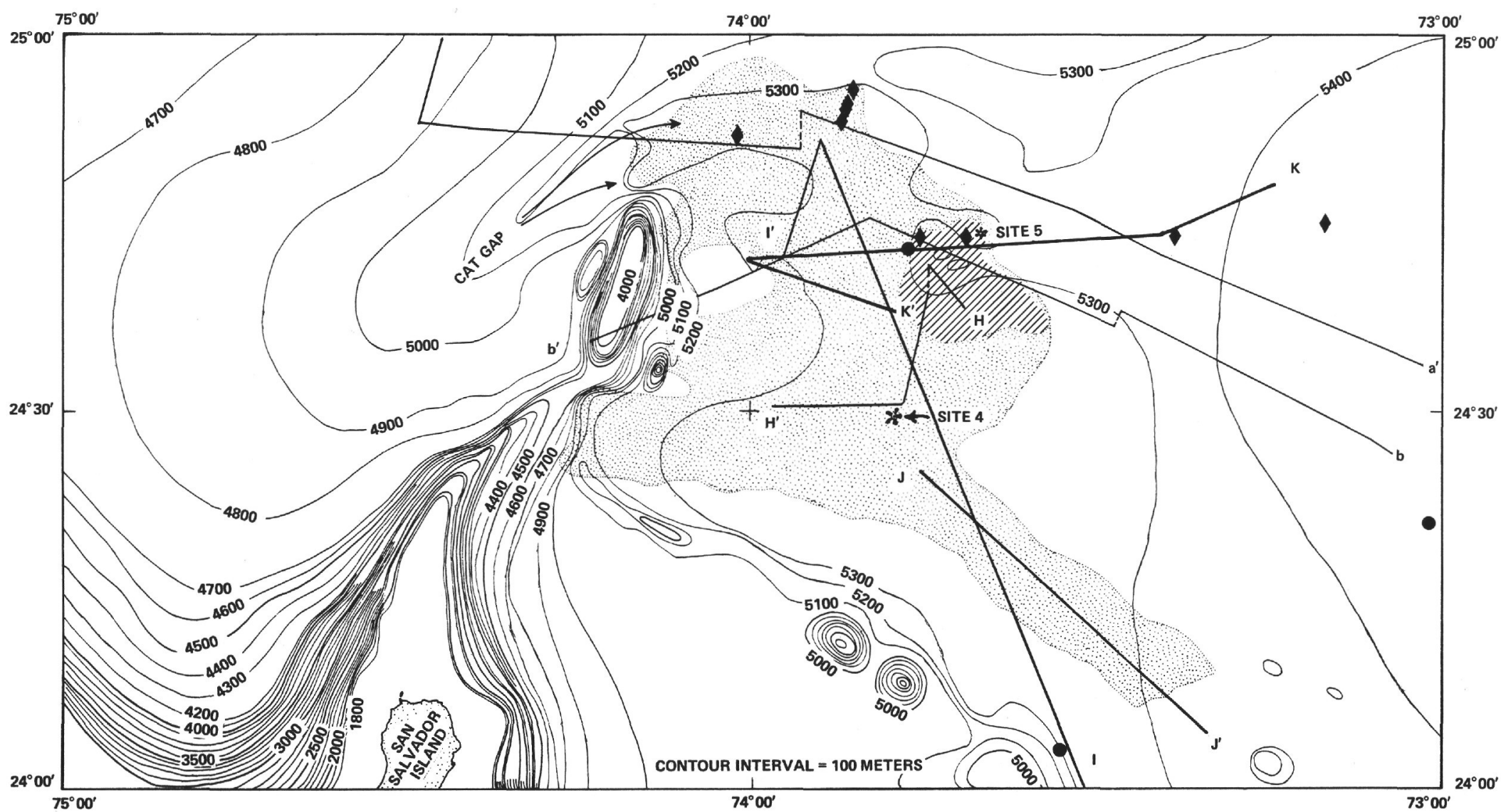

Figure 10. Bathymetric chart of seismic Horizon $\beta$ outcrop area, showing Sites 4 and 5, and the results obtained by piston coring. Outcrop of $\beta$ is stippled, and the oldest outcropped sediments are indicated by hachures. Solid diamonds indicate Cretaceous cores; solid circles indicate Miocene cores (after Windisch et a1., 1968). 
Hence, Site 5 (Figure 13) was chosen near a basement elevation in the hope of obtaining a compressed section with limited penetration. (Profiler traverses through the site itself are unavailable pending the Vema site survey.) Site 5 was located in the deepest water yet drilled, 5354 meters $(17,567$ feet), and the oldest rocks known from the deep oceans-late Jurassic-were recovered.

By combining the core data from both sites, nearly every Tertiary and Cretaceous stage has been identified.
The total sequence is unusually thin; approximately 250 meters of sediment appear to represent about 125 $\times 10^{6}$ years of time, an overall sedimentation rate of only $2 \mathrm{~mm} / 10^{3}$ years. This order of magnitude is lower than the apparent rate for organic pelagic deposits, and a rate certainly not suggested by the abundant turbidites present. Rather than being the result of an extremely low rate of sedimentation, the very thin section in this area appears to be due to many small gaps in the sequence. Throughout the Tertiary and Cretaceous this
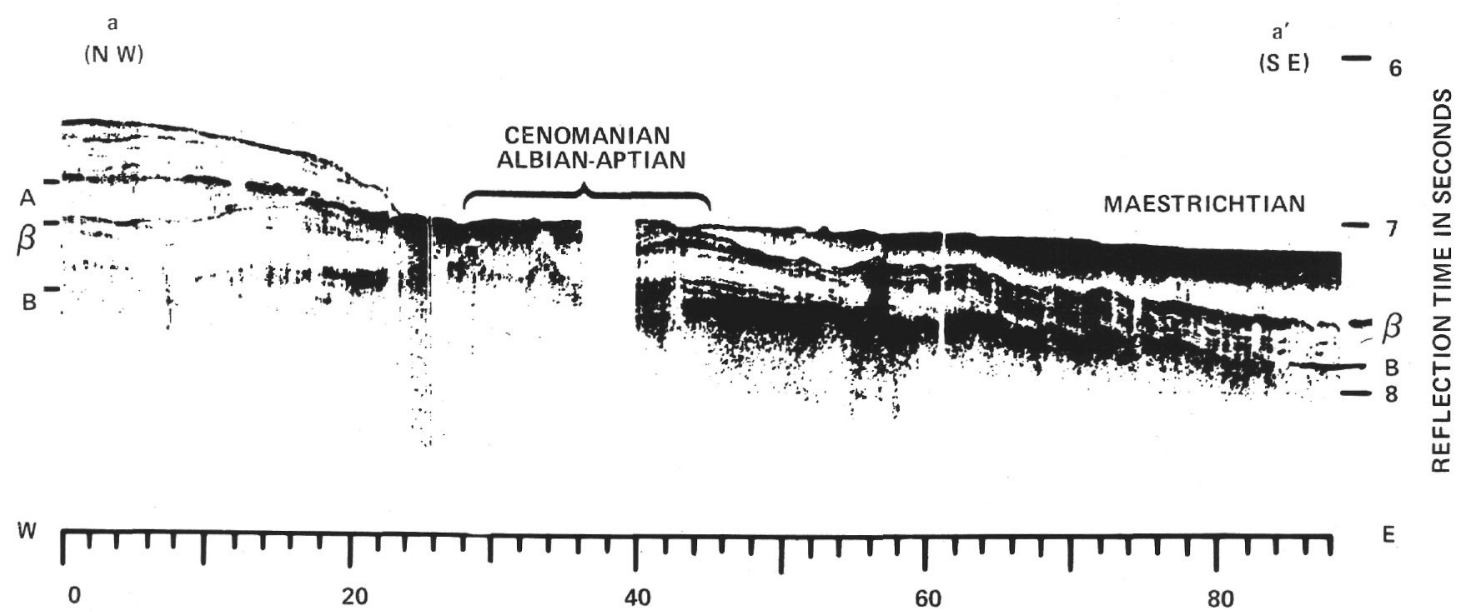

SCALE IN NAUTICAL MILES

b

(E) $b^{\prime}$

(W)

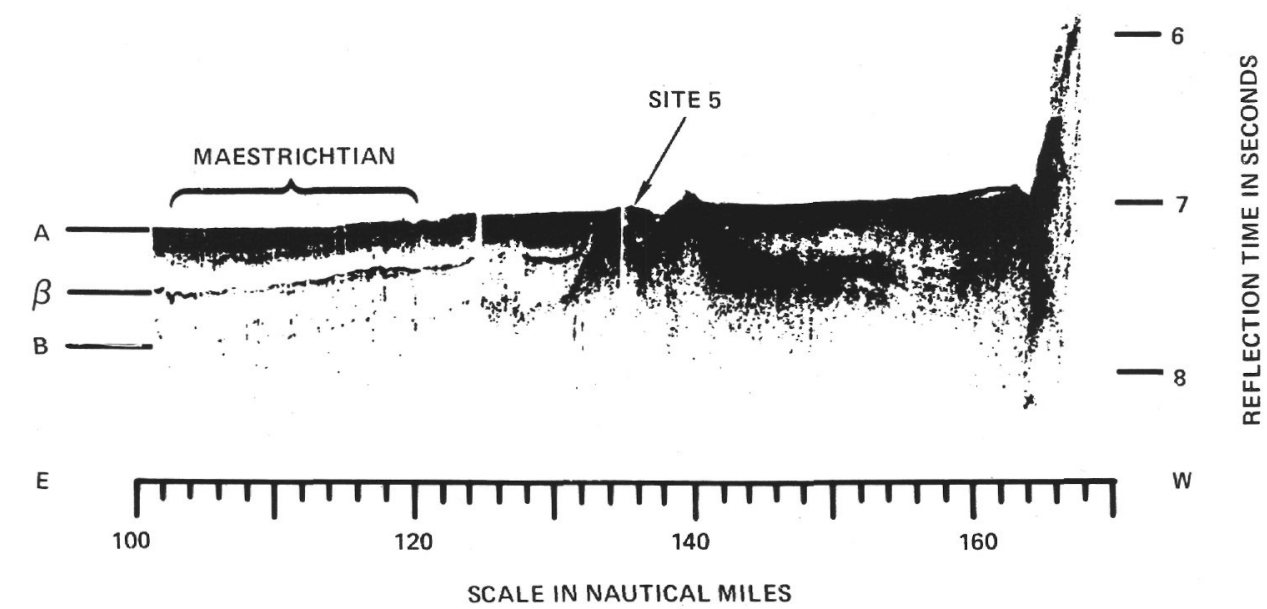

Figure 11. Seismic sections through the Horizon $\beta$ outcrop area, showing ages assigned on the basis of piston coring. Profiler tracks are indicated in Figure 10. One second of reflection time is 760 meters water depth. 


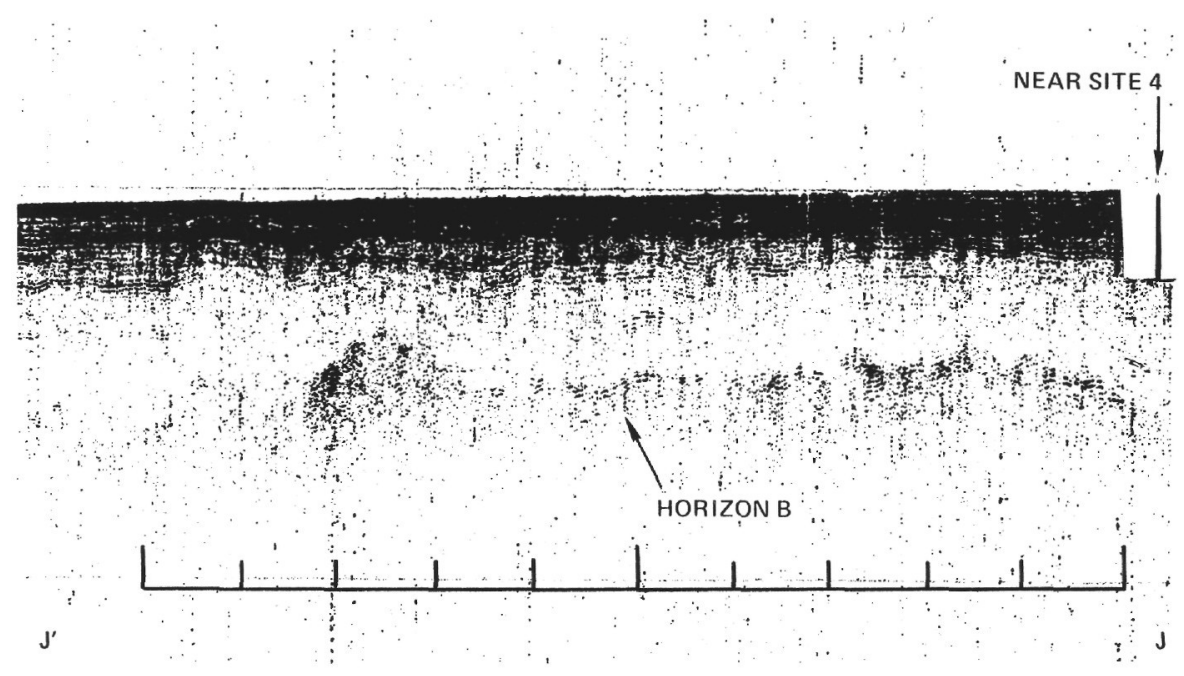

Figure 12. Seismic section near Site 4. showing Horizon $B$ far beyond the maximum penetration achieved. Profiler track is indicated in Figure 10. (Robert D. Conrad-10, 3 Oct. 1966, 0700-1000).

area was one which was largely bypassed; most of the sediment was swept away, and it is only intermittently that some was preserved-a situation which seems to have persisted until the present.

In general, carbonate turbidites dominate the Tertiary and Cretaceous. These consist of calcareous, shelfderived organic debris and reworked calcareous and siliceous pelagic oozes. Silicified siltstones and cherts are most abundant in the lower part of the Cretaceous and in the uppermost Jurassic. These sediments are interbedded with lesser amounts of normal, organic, pelagic oozes. This sequence of sediments strongly suggests that, at least since latest Jurassic, the conditions of deep-water sedimentation were not noticeably different from those of today. An equal, undrilled thickness of sediment seems to underlie the sequence already cored, indicating the presence of sediments at least well back into the Jurassic.

Various components of the sediment suggest sources ranging from the mainland shelves of North America to the Blake Plateau and Bahama Platform areas, and possibly the Greater Antilles. A large part of the material is resedimented organic oozes, much of it calcareous. This suggests that calcareous material can be preserved below the depth of carbonate compensation if it is brought into this environment rapidly enough and in large enough quantities-as by turbidity currents. This is even more apparent at Sites 6 and 7. It is also this allochthonous material which is most unstable and most susceptible to lithification, diagenesis and cementation, Many of the calcareous turbidites are hard chalks or limestones interbedded with watery oozes, and many of the calcarenites are completely silicified.
The data from piston cores previously noted indicates that Horizon A in this area lies close to the CretaceousTertiary boundary. Seismic reflection data suggest that at least locally this interval is an important unconformity (e.g., northwest edge of outcrop area). Horizon $\beta$ is apparently marked by the mid-Cenomanian unconformity noted by correlation between Sites 4 and 5 in Figure 14. This unconformity also can be recognized on seismic reflection data-it being prominent in the north and east of the outcrop area, but unrecognizable to the south and west of Mt. Reproach. Horizon B was not reached because of the drilling problems encountered with cherts, but the reflection profiles suggest strongly that it also may be partly or largely sedimentary. Prominent magnetic anomalies near Mt. Reproach indicate that volcanic rocks might also be involved in beds below Horizon B.

The reflection profiles show Horizon $\beta$ to be sharply bowed up around the flanks of Mt. Reproach, and that the uplift largely occurred later than the $\beta$-unconformity; there is also some suggestion of earlier growth. The dip of the beds observed in the cores at Site 5 increased to nearly 20 degrees at the deepest penetration, and it is likely that only a small part of this was due to hole deviation. Block faulting is also prominent in the details of many of the reflection profiles. It thus seems to be demonstrated that structural deformation and complications on a small scale are not to be unexpected in the deep ocean.

\section{BERMUDA RISE}

The Bermuda Rise is a broad topographic swell approximately elliptical in shape. Its major axis extends about 


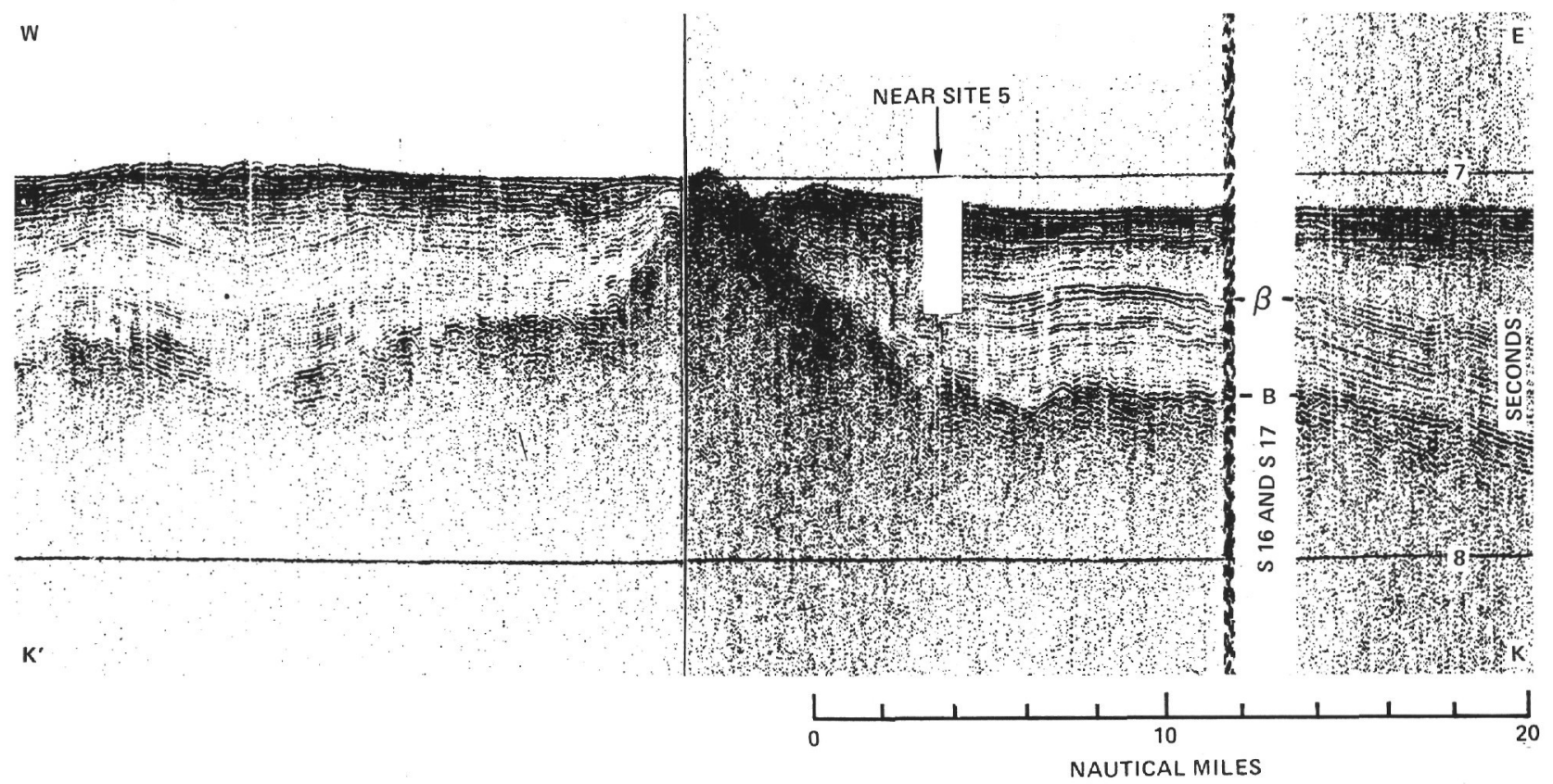

Figure 13. Seismic section near Site 5. Profiler track is indicated in Figure 10 (Vema-22,23 Jan. 1966, 1100-2230).

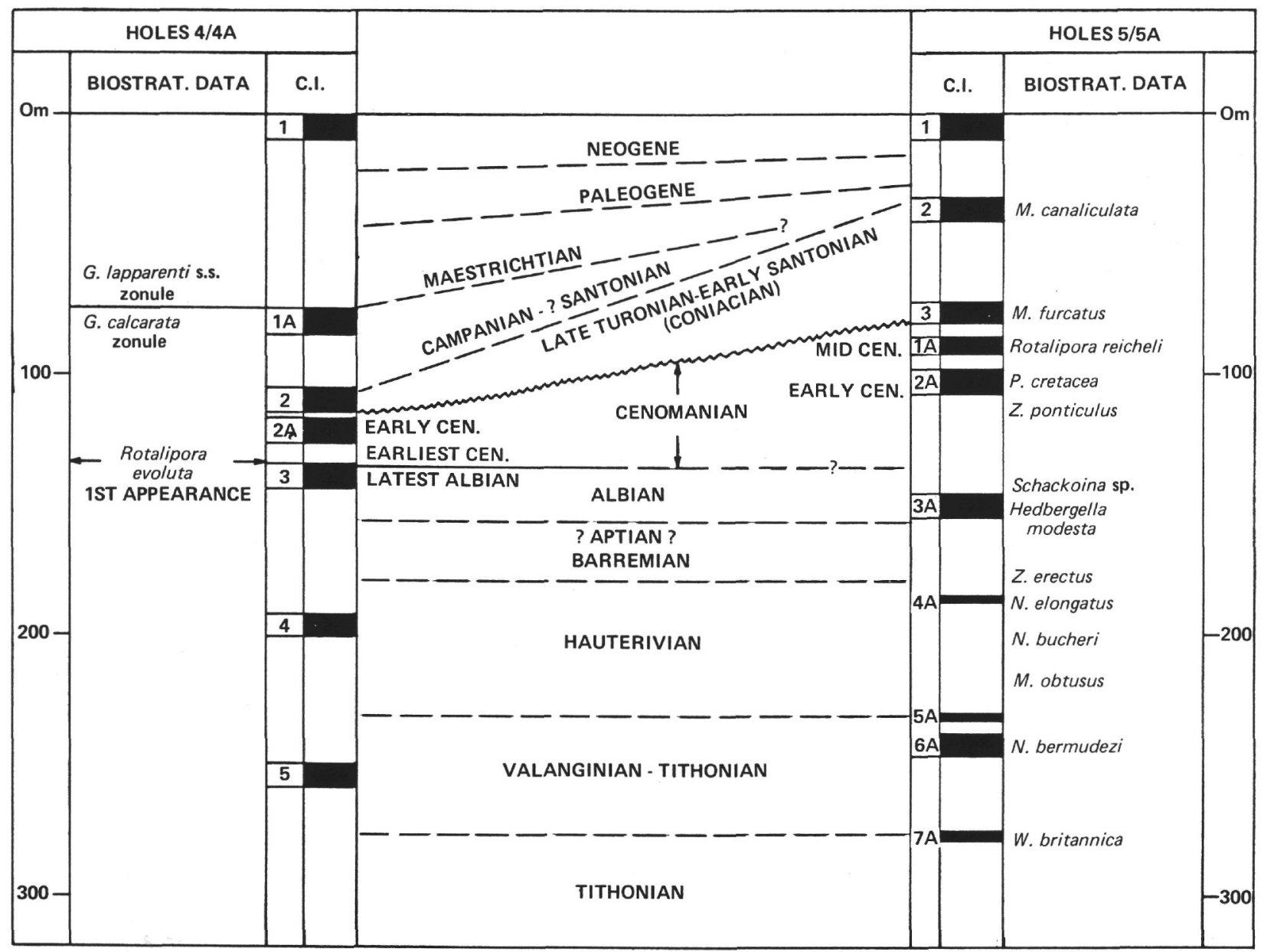

Figure 14. Stratigraphic correlation of Sites 4 and 5. 


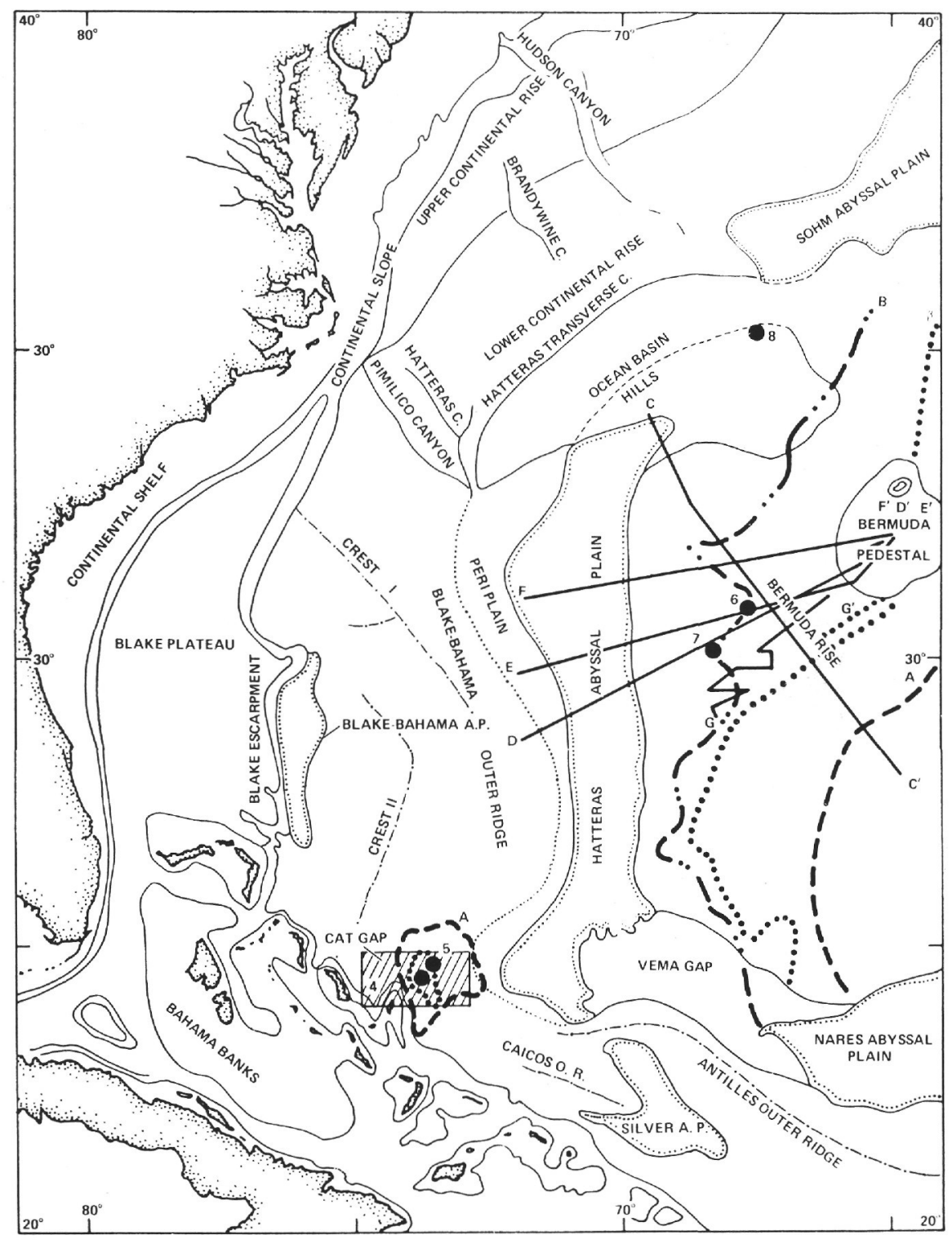

Figure 15. Regional chart of Bermuda Rise area showing locations of Sites 4-8 and the eastward limits of Horizons $A, \beta$, and $B$ as mapped by these and several other traverses (after Schneider, 1969). 
2000 kilometers $(1100 \mathrm{~nm})$ in a northeasterly direction from about $23^{\circ} 30^{\prime} \mathrm{N}, 68^{\circ} 00^{\prime} \mathrm{W}$ to about $39^{\circ} 00^{\prime} \mathrm{N}$, $56^{\circ} 30^{\prime} \mathrm{W}$. The minor axis is about 1000 kilometers in length. The Bermuda platform is near the center of the ellipse. Broadly speaking, the northwest half of the Rise has a considerable cover of sediment, with the reflectors $\mathrm{A}, \beta$, and $\mathrm{B}$ extending to the limits shown in Figure 15. The southeast half is devoid of continuous sediment cover-the transition between the two being rather abrupt. The Kelvin Seamount group produces considerable disturbance of the sediment cover, as it cuts across the northeast end of the Rise, as does the Muir group at about $33^{\circ} \mathrm{N}, 63^{\circ} \mathrm{W}$.

Despite this, the sediment cover in the northeast part is more acoustically homogeneous and more uniform in thickness than elsewhere. Abyssal plains almost surround the Rise: the Sohm Abyssal Plain being on the north and northwest boundary; the Hatteras Abyssal Plain on the east; and the Nares Abyssal Plain on the south, as indicated in Figure 15. In the central eastern part at the boundary of the Rise, the abyssal hills province occupies the interval between the Rise and the flank of the Mid-Atlantic Ridge. Reflectors A and $\beta$ have not been recognized in the areas of thin sediment cover mentioned above (Ewing et al., 1966).

In Figures 16,17 and 18 several profiler traverses, $\mathrm{CC}^{\prime}$, $\mathrm{DD}^{\prime}, \mathrm{EE}^{\prime}$, and $\mathrm{FF}^{\prime}$, are reproduced in order to show various features of the Bermuda Rise in relation to Sites 6 and 7. The locations of these traverses are shown in Figure 15. From these traverses, it is seen that, except for local disturbances by basement peaks, the various reflectors (particularly Horizon A) rise gradually from their depth of about 8.7 seconds reflection time near the abyssal plain and Bermuda Rise boundary to about 7.2 seconds in the vicinity of Sites 6 and 7.

Contrasting theories have been noted relative to the nature of Horizon $\mathrm{A}$ in this area, and the origin of the Bermuda Rise. If Horizon A is a unique event in pelagic sedimentation, it would require no significant uplift in the Bermuda Rise. Conversely, if it is an ancient turbidite interval (Ewing and Ewing, 1962), younger arching and uplift of the Bermuda Rise would be required.

Sites 6 and 7 were both well up on the southern flank of the Bermuda Rise. Site 6 was situated in a depression over the rough basement, while Site 7 was located over a local basement high where the beds below Horizon A were greatly thinned. In both localities the upper part of the sequence sampled in the cores consists of brown deep-sea clay, barren of fossils except for spores and pollen. These clays appear to overlie an interval of mid-
Eocene turbidites which correspond to the topmost member of the Horizon A sequence.

The general history revealed by these sediments is one of an abyssal plain which until early mid-Eocene was open to the influx of debris from the Atlantic shelf of North America and perhaps from the Greater Antilles. Later in the Eocene the turbidite influx stopped and deposition of deep-sea clays dominated the area, either because of uplift of the Bermuda Rise or subsidence of the Hatteras-Sohm abyssal plain region to the west. The regional characteristics of the Bermuda Rise suggest that a broad uplift is the more reasonable explanation. The eastern limit of the area of early Cenozoic turbidite deposition is indicated in the vicinity of $65^{\circ} \mathrm{W}$ in Figure 15.

The base of this mid-Eocene turbidite sequence was penetrated at Site 7, and older deep-sea clays were recovered. These clays contain no diagnostic fossils, show prominent color banding and irregular layering, and are rich in ferric clays (hematite). It seems reasonable that sediments of this sort are the natural result of dewatering, compaction and burial of normal deep-sea clays. Since Site 7 was situated on a local topographic high, it is possible that these older clays correspond to a thinned and pelagic sequence, while the thicker adjacent sediments may represent abyssal plain turbidites of identical age. This interpretation suggests that the topographic lows would have been filled with sediments by mid-Eocene, at which time the turbidites would have finally crossed over the topographic high at Site 7.

Alternatively, if any general pattern of deep-ocean sedimentation can be estimated from these first few deepwater holes, it is that there appear to be surges of turbidite deposition, gradually becoming thinner and less frequent with time, and finally giving way to largely pelagic sedimentation. The mid-Eocene turbidites may thus represent the start of such a cycle and the underlying clays may be the waning phase of the preceding cycle. The facts that Horizon A is widespread in this area, and of the same age at both Sites 6 and 7, and is underlain everywhere here by acoustically transparent beds, all suggest that this older clay is of regional rather than merely local importance. If Horizon $\beta$, which is present throughout much of this region, also consists of turbidites, the broader importance of these older clays must be considered as the most reasonable alternative. The truth may ultimately lie somewhere between these two alternatives.

The mid-Eocene turbidites consist normally of a basal unit of olive sand or silt, chiefly of benthonic foraminifera (including reworked Cretaceous forms), quartz, 


\section{$\therefore$ ir}

8002

16004

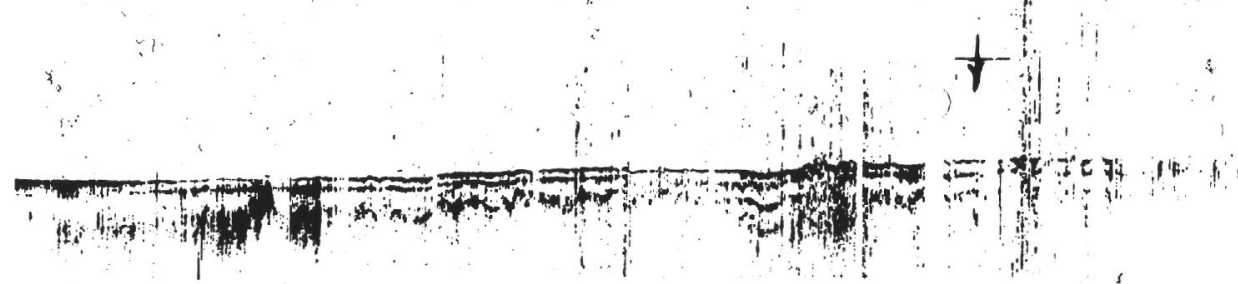

24006

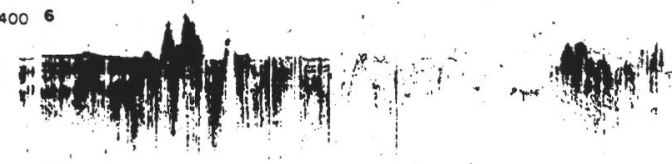

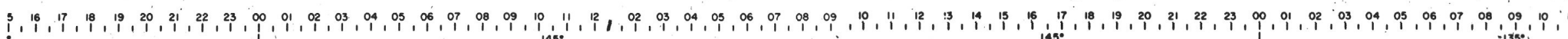

16 FEgruary 14 February

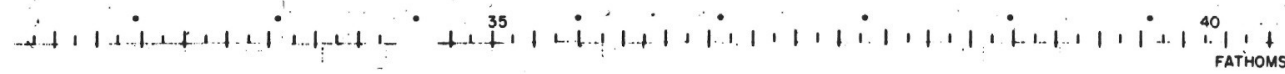

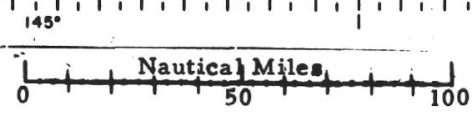

$E^{\prime}$

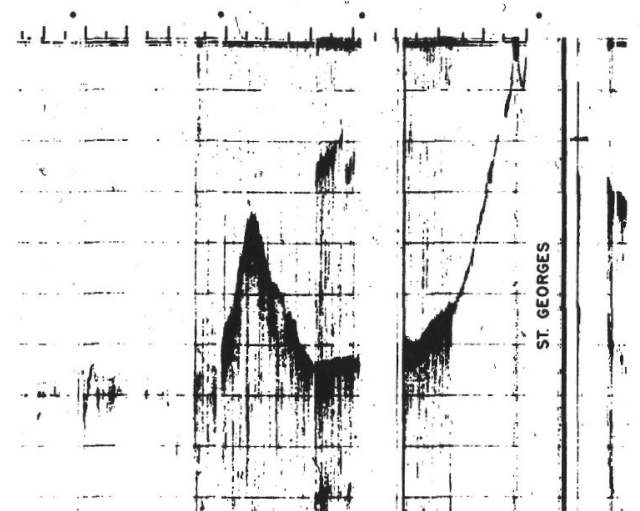

$21,22,23,00,02,03,04,06,07,08,09,10$

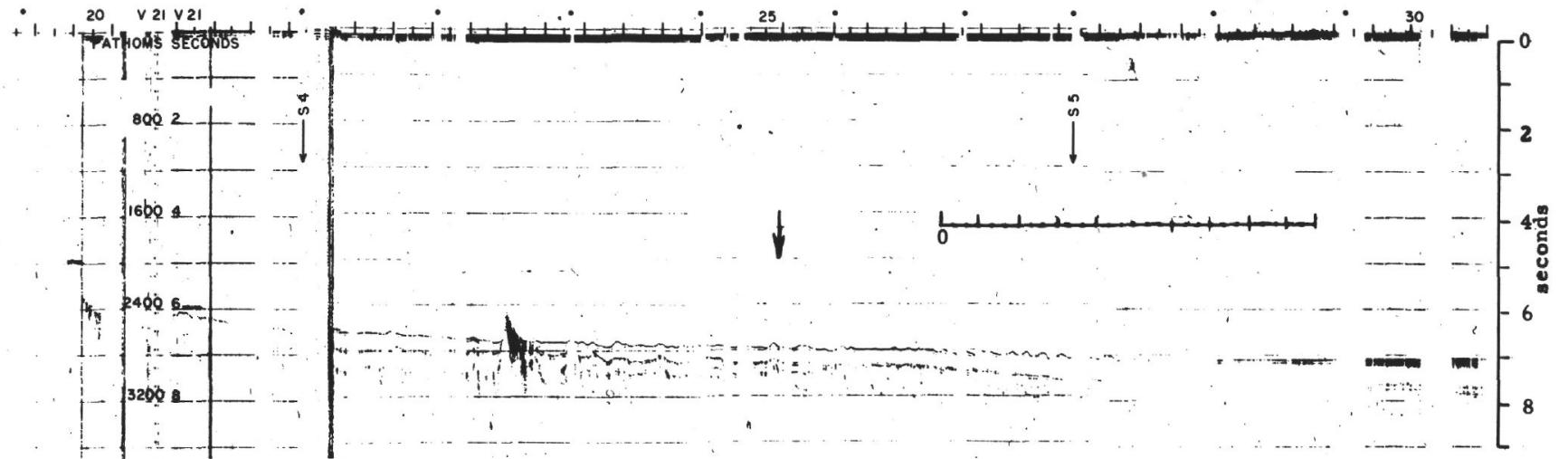

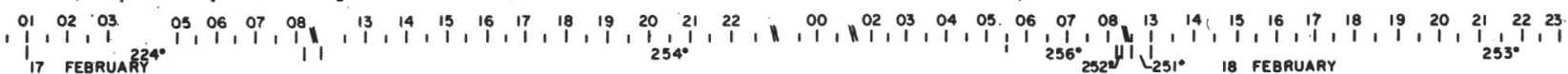

Figure-16. Profiler traverse $C C^{\prime}$ and EE' of Vema-20 and Vema-21, near Sites 6 and 7. Locations are given in Figure 15. 


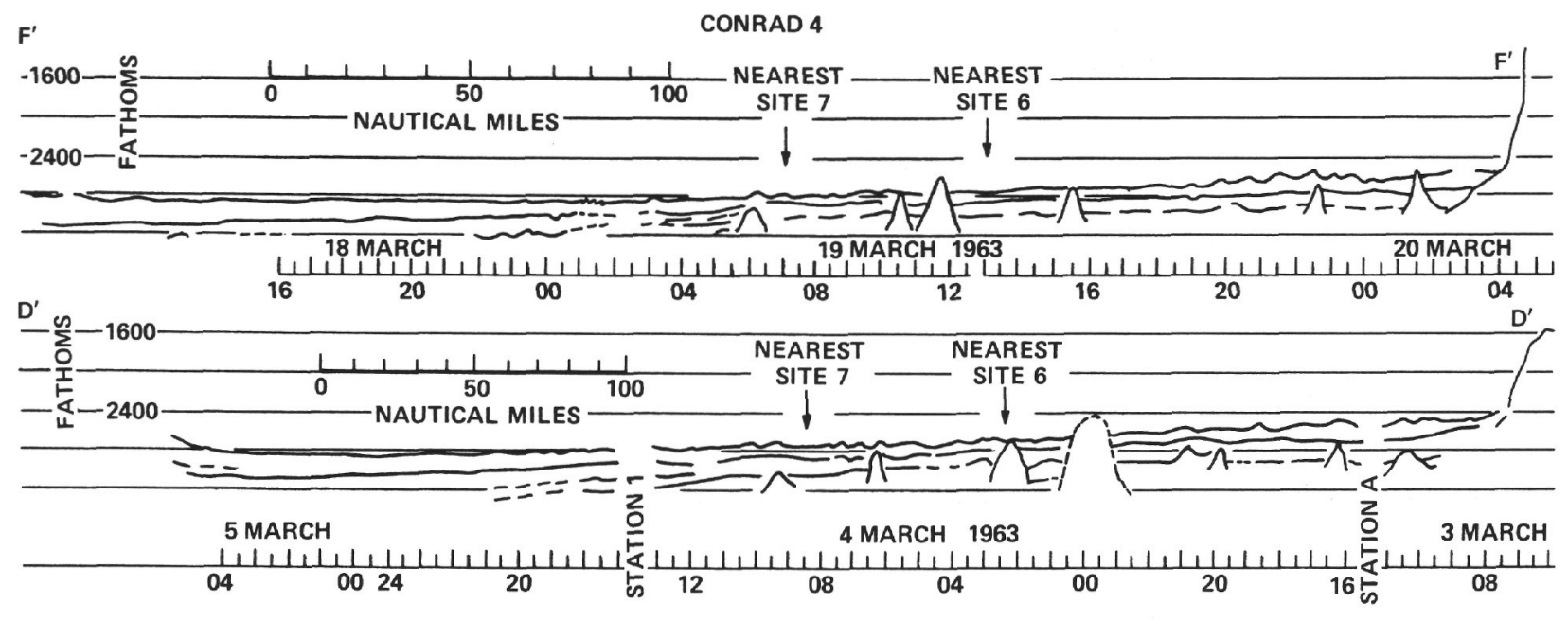

Figure 17. Profiler traverses $F F^{\prime}$ and $D D^{\prime}$ of Robert D. Conrad-4, near Site 6 and 7. Locations are given in Figure 15.

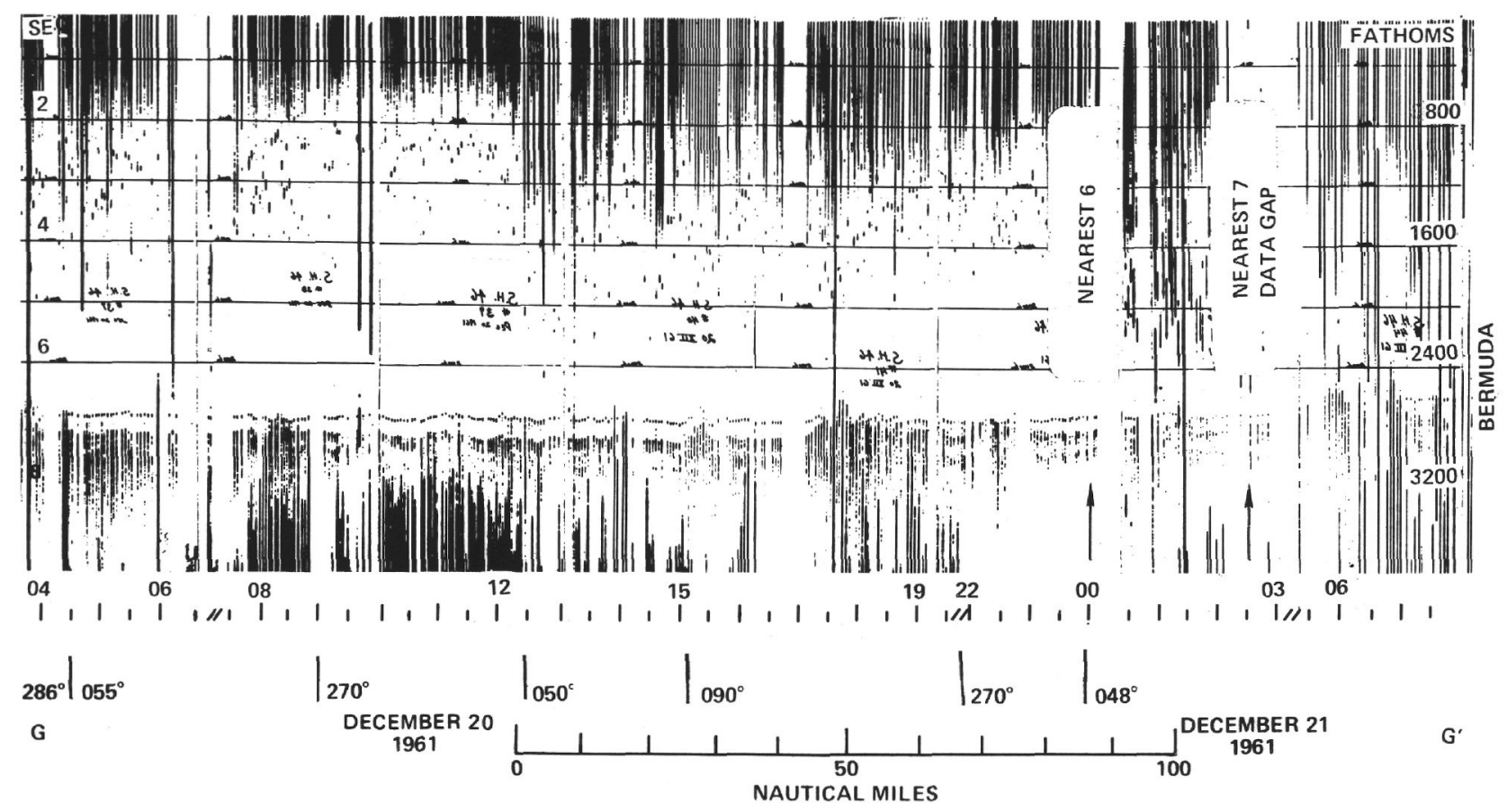

Figure 18. Profiler traverse $G G^{\prime}$ from Sir Horace Lamb, near Sites 6 and 7. Locations are given in Figure 15. 
large sponge spicules and glauconite, and an upper unit of greenish coccolith ooze or chalk, with an admixture of small spicules and Radiolaria. The upper pelagic part of the cycle is typically a bluish-green diatom ooze. These allochthonous sediments are commonly highly silicified, forming thin beds of chert which increase in thickness and frequency toward the base of the sequence. Horizon A was indicated to occur somewhat below the depth of the shallowest cherty bed, and it seems that such beds must be present in excess of a minimum abundance or frequency or thickness before they can serve as adequate reflectors.

This region also emphasizes the large extent to which turbidites incorporate and resediment deep-water pelagic deposits. As noted in previous holes, carbonates can apparently be preserved below the depth of calcite compensation when they are brought into that environment in sufficiently large quantities and within a short time interval-as in the case of turbidites. It is unlikely that the mid-Eocene depth of compensation was significantly deeper than that of today, or that this area has been lowered since the Eocene; all of the regional data suggest that any broad crustal movements have been in uplift. Furthermore, the mid-Eocene pelagic component is a siliceous ooze, pointing out that the interbedded calcareous turbidites were emplaced below the depth of compensation.

The discovery of early Cenozoic radiolarian cherts at all four Atlantic sites greatly increases the areal extent of the similar sediments recovered by piston coring on a fault scarp in the Caribbean Sea (Edgar 1968; Ewing, Edgar, and Antoine, in press). At the time of that discovery the extension of a radiolarian fauna east of Panama was attributed to interruption of the isthmus barrier.

\section{GENERAL COMMENTS}

It is evident from the results of this pioneering cruise in deep-ocean drilling that the Glomar Challenger and its system work well, and that it can provide a vast wealth of data which will significantly improve our understanding of the earth on which we live and from which we extract our natural resources. Many scientists have long emphasized the need and value of such a deepwater coring program (cf. Hedberg and Burk, 1964).

It is the hope and expectation of the scientific staff aboard this first leg that this exciting project will continue to flourish and that with continued experience the capabilities will continue to increase for greater depth of coring and for wider ranges of operation. It is also our belief that marine geophysical studies are entering into a new phase of productive value, since these surveys can now be tied to known rocks, of known ages, and known composition.

The indication that chert layers may be of widespread extent has introduced a serious obstacle to deep penetration of deep-sea sediments and emphasized the need for development of a system for hole re-entry.

\section{REFERENCES}

Edgar, N. T. "Seismic Reflection and Refraction in the Caribbean Sea." (Unpubl.Ph.D thesis, Columbia University, 1968.)

Ewing, J., Edgar, N. T., and Antoine, J. (in press). Caribbean and Gulf of Mexico Structure. In The Sea, Worzel, J. L. and Maxwell, A. E. (Eds.). New York (Interscience) 4.

Ewing, J. and Ewing, M., 1962. Reflection profiling in and around the Puerto Rico Trench. J. Geophys. Res. 67, 4729 .

Ewing, J., Worzel, J. L., and Ewing, M., 1962. Sediments and oceanic structural history of the Gulf of Mexico. J. Geophys. Res. 67, 2509.

Ewing, J., Worzel, J. L., Ewing, M., and Windisch, C., 1966. Ages of Horizon A and the oldest Atlantic sediments. Science 154 (3753), 1125.

Ewing, M., 1963. Sediments of ocean basins. In Man, Science, Learning and Education. S. W. Higginbotham (Ed.). Houston, Texas (Wm. Marsh Rice Univ.), 41.

Ewing, M., Worzel, J. L., Ericson, D. B., and Heezen, B. C., 1955. Geophysical and geological investigations in the Gulf of Mexico, Part I. Geophysics 20, 1.

Hedberg, H. D., and Burk, C. A., 1964. Drilling the ocean crust. Intern. Science and Technology. (34), 72.

Schneider, E. D. "Geologic investigations in the western North Atlantic." (Unpubl. Ph.D thesis, Columbia University, 1969.)

Windisch, C., Leyden, R. L., Worzel, J. L., Saito, T., and Ewing, J., 1968. Investigation of Horizon $\beta$. Science. 162 (3861), 1473.

Worzel, J. L., Leyden, R., and Ewing, M., 1968. Newly discovered diapirs in the Gulf of Mexico. Bull. Am. Assoc. Petrol. Geologists 52, 1149. 